\title{
$\mathrm{Cu}-\mathrm{Al}$ 合金の內部摩擦についで
}

\author{
高橋修一郎** 今 野 熙**
}

Shuichiro Takahashi and Hiroshi Konno: On the Internal Friction of $\mathrm{Cu}-\mathrm{Al}$ Alloys. The internal friction and the Young's modulus of $\mathrm{Cu}-\mathrm{Al}$ alloys with 0 to 16 weight par cent of aluminium were measured at room temperature using free transversal vibration of about $1000 \mathrm{cycles} / \mathrm{sec}$. An alloy of martensitic structure has an extremely high internal friction $1-2 \times$ $1^{-3}$ ), which is independent of various retreatments of specimens, such as casting, forging, annealing at $620^{\circ}$, and quenching from $800^{\circ}$, seemingly remaining constant over the frequency range 300 to $7000 \mathrm{cycles} / \mathrm{sec}$ and showing a very low Young's modulus $\left(7.5-8.8 \times 10^{3} \mathrm{~kg} /\right.$ $\mathrm{mm}^{2}$ ). The internal friction of the alloy consisting of $\alpha$ and $\beta^{\prime}$ phases is governed by the quantity of the martensitic structure. The internal friction of $a$-phase depends largely on the pretreatment of the specimen; its value increases with an elevation of the quenching temperature, and decreases with increasing concentration of aluminium according to a power fuction. The $\boldsymbol{\gamma}$-phase has a very low internal friction, and a high Young's modulus.

(Received April 18, 1955)

I. 緒

** 三菱金廍鑛業株式會社鑛業研究所

* 1952 年11 月本會稫岡大會に發表
アルミニウム青銅で最も廣く用いられているのはアルミ =ウム含有量 $8 \%$ 以下の $\alpha$ 相(f.c.c.) と約 8 12\% での $a+\beta^{\prime}$ 相のものである (Fig. 2). ここで, $\beta^{\prime}$ 相は高 溫に特いて $\beta$ 相 (b.c.c.)のものが低溫に燒入れた場合に 
生じる中間相で, 所謂 martensitic 組織である. $\boldsymbol{\beta}^{\prime}$ 相は 不安定で當然多くの歪を內在させているので，この組織を



Fig. 1 Schematic diagram of the aparatus for measuring internal friction and Young's modulus.

持つ試料を 振動狀熊に 置くと大き な內部摩擦 を生じるこ とが豫想さ れる.また， ๙ 相ではア ルミニウム
の濃度が雷加すると轉位の移動を拘束するので，轉位に起 因与る內部摩察が減少することが豫想される(1)(2)(3)。この 二つの豫想をたしかめるためにアルミニウム成分が 0〜16 \%までの $\mathrm{Cu}-\mathrm{A} 1$ 合金の內部藦察と彈性率を鑄造, 鉣造呿 よび熱處理狀態について測定した.

\section{II. 試料および測定方法}

高周波電氣爐に入れた黑鉆電極製ルツボ中で，木炭で被 㠅して高純度銅（三菱金屬製，99.99\%) を溶解し，十分還 元性雾湋氣中に置いた後，微量つ燐銅で脫酸して所定の高 純度厂ルミニウム（日新化學製, 99.99\%）を投入し,攪汼, 顉静の後 $10 \mathrm{~mm}$ 角と $20 \mathrm{~mm}$ 角鑄型に傾斜鑄造した. 前 者は $150 \mathrm{~mm}$ に切斷して鑄造試料とし，後者は $800^{\circ} よ り$ $600^{\circ}$ の間で $12 \times 12 \mathrm{~mm}$ まで銭造した後 $10 \times 10 \times 100 \mathrm{~mm}$ にシェーパー加工して熱處理試料とした。機械加工のとき は兩者とも發熱しないよらに注意した. 製作した試料のん ルミニウム成分（分析值）は $0.00,0.03,0.08,0.54,1.38$, $2.99,5.56,8.50,9.13,9.40,10.0,10.53,11.47,12.08$, 12.30,12.80,13.3,14.03 特よび 16.0 wt\% である.

測定に用いた裝置(4)の略圖を Fig. 1 に示した.上記の 內部摩祭試铪片の兩端に約 $0.85 \times 2 \times 10 \mathrm{~mm}$ の鐵片をセ メダインで付着し，固有振動つ節になる 2 點占絹系で吊し

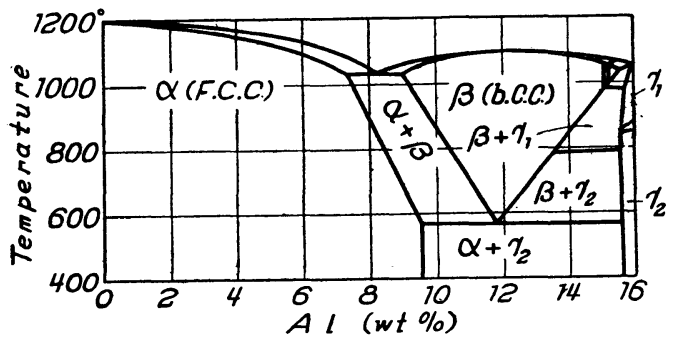

Fig. 2 Equilibrium diagram of copperaluminium alloys.

(1) F. Seitz, Imperfections in nearly Perfect Crystals (Symposium held at Pocono-Manor), (1952), 3.

(2) J.S. Koehler, " " 197.

(3) J. Marx, J.S. Koehler, A Symposium on the Plastic Deformation on Crystalline Solids, Mellon Institute, (1950), 171.

(4) 高橋, 本誌, B-16(195?), A-15.
た. $\mathrm{CR}$ 發振器の主コンデンサー $(0.0474 \mu \mathrm{F}) に 500 \mathrm{PF}$ の精㣰級可變コンデンサーを並例に連結させた發 振 裝 置 で, 試料の固有振動數附近の振動を發 振させるとその電

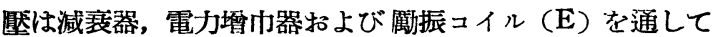
電磁的に試料をその一端加ら赝振させる. 試料の 振動の 大きさと位相は受信コイル (R) によつて試料の他端より 電磁的に受信し值線增巾器で習巾しブラウン管の縱軸また は電磁オシログラフに入れて測定した。電磁オシログラフ を用いる場合は, 㔠振と試料の振動の位相差を見ることは 振動數がきわめて小さい時以外は困雖であるが，ブラウン

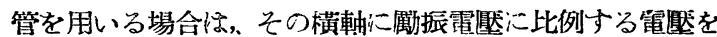
入れて Lissajous 圖形を畫かせると，豫め電篓回路から來 る位相差を測定して置くと, 圖形の形狀方ら庽振と試料の 振動の位相差を簡單に面哯できるので共鳴狀況を知るのに きわめて有利である，臹受振マダネットと試料の間隔は $1 \mathrm{~mm}$ にして，振巾と電壓が比例するようにした，測定に 際してはまず受信增巾器の增巾率 (A) を最大にし，發振 裝置の振動數を變えて，共鳴狀態にする．このさい振巾を 餘り大きくしないように注意する（大きくして塑狀變形さ せると內部摩䏅が變わる)のみでなく,ブラウン管上の縱の 振巾を特定振巾になるよらに凲振側の減衰器を調整した。 內部摩擦の大きさは，その値が大きい試料については可變 コンデンサーの角度を變えて共鳴曲線を取りその 1/2巾よ

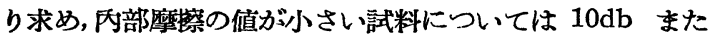
は $15 \mathrm{db}$ 間の自然減衰時間より求めた. またこの折の共鳴 振動數より彈性率を求めた. 次に受振增巾率 (A) を 5 $\mathrm{db}$ または $10 \mathrm{db}$ 置さに減少させ，ブラウン管上に前と同 じ振巾と位相を持つように庽振動數と減衰器を調整し同樣 な測定を行い，最後に顯微鏡で測定できる程度の大振巾に した際に振巾の絕對値を測定した. かくして 10-5 〜10-4 $\mathrm{mm}$ より $10^{-1} \mathrm{~mm}$ の振巾範圍を $5 \mathrm{db}$ または $10 \mathrm{db}$ 固 きに實測した。 また測定に周いた 振動型は主として兩端自 由の基準振動（約 $1000 \mathrm{cycles} / \mathrm{sec}$ 程度）で, 測定は常溫 である.

な特本測定に用いた發振器は特に安定度のよいものを選 び，また電源として電池と定電慰裝置を並列に結んたミもの を用いているので時間的變化も少ない. 絕對值は 1000 cycls/sec の放送標淮電波を椆いて較正した。それ故測定 层動數は有效數字5析まで信賴出來る。



上述のように $10^{-5} \sim 10^{-4} \mathrm{~mm}$ 程度の小振巾で測定した 後，穴第にその脤巾を大きくして行くとある特定の振巾ま では內部摩擦と彈性率はほぼ一定であるが，その振巾を超 すと內部藦蔡は急激に上昇し彈性率は低下する. このこと はさきに亞鉛の單結晶について報告したが(5)，銅合金の場 合む(單結晶でも多結晶でも)同漾である.この臨界振巾は

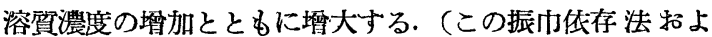
び臨界振巾については別に報告する）以下この臨界振巾以 
下でつ內部摩察を振巾非低存內部摩察とよぶことにする.



(1) 內部家擦

鑄造狀態刀振巾非传存汹部摩摖と金屬組 織との關係は

Fig. 3 の如くであつて, 次の五つの部分にわかれてい

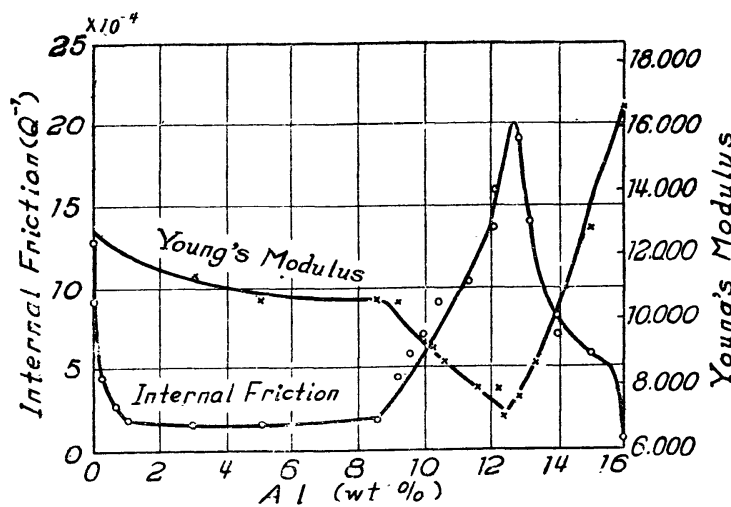

Fig. 3 The effect of aluminium content on the internal friction and Young's modulus of cast spesimens of $10 \times 10 \times 150 \mathrm{~mm}$.

る.

(a) 第一に $1 \% \mathrm{Al}$ 以下の部分では $\mathrm{Al}$ が多くなるに從 つて内部摩祭心 $1.3 \times 10^{-3}$ 上り 約 $1.6 \times 10^{-4}$ をで票函 數的に減少している. (b) 第二に $1 \% \mathrm{Al}$ より $8 \% \mathrm{Al}$ までの合金で湾ほとんど一定である. (c) 第三に $8 \%$ か ら洪昆點約 $12 \%$ までの領域ではフルミニウムが的すに 從つて墂加し，共晶哭で最大值を示している．その大き

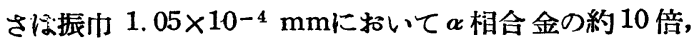
振巾 $1.68 \times 10^{-3} \mathrm{~mm}$ に扔いて $a$ 相合金の約 20 倍に達 ナる. (d) 第四には $12 \%$ より $15.5 \%$ までの領域では フルミニウムの或分の增加とともに內部摩祭は急激に減少 している. (e) 最後に $15.5 \%$ 以上のアルミ成分の領域の 測定は 1 點しかないが, 內部摩摖は $6.8 \times 10^{-5}$ であつて 非常に小さい. 金型鑄造のま〉でこのような小さい內部摩 擦つ值を持つものばづらしい，また，振動振巾を1.68x

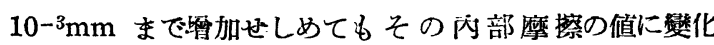
はない.

\section{(2) 弹性率}

上記镐造のま〉の試料つ:笒鳴振勤數よ り彈性率を測定した結果は Fig. 3 にX 點をつなぐ默楾で示した通りである.鑄 造品であるので厚みの測定の誤差のため 湘定值深や〉低めに出ているのみでなく 䋖動む多いが, 內部摩祭の測定結果と同 様に組織に上り顯菩な差を示している. この結果によれば前記の領域 (1) と (2) は同一の頑向を示し，彈性率は純銅の $12,500 \mathrm{~kg} / \mathrm{mm}^{2}$ よりアルミニウムが酒加 ナるにつれて第に隇少している. 次に
約 $8 \%$ より $12 \%$ まですなわち前記領域（3）において, テルミニウムの成分が滑加すると彈性率浨急激に一娍少し， $12 \% \mathrm{Al}$ において $7,000 \mathrm{~kg} / \mathrm{mm}^{2}$ を示している. 最後に $12 \%$ より $16 \%$ までの領域ではアルミニウム成分ととも に急激に壻加し $16 \% \mathrm{Al}$ では約 $16,000 \mathrm{~kg} / \mathrm{mm}^{2}$ の值 を示している.

\section{2. $540^{\circ} 12 \mathrm{hr}$ 熱豦理後の測定蛣橗}

上記鑄造品を $\approx+\gamma_{2}$ 變熊の最る蒌かに起ると思われる 溫度 $\left(540^{\circ}\right)$ にて $12 \mathrm{hr}$ 熱选理後, 熥中にて $100^{\circ}$ まで徐冷 （約 6hr）して取り出し，室温に澾した後に彈性率と內部 摩蔡を測定した繥果はそれぞれ Fig.4 の × 點拈よび○ 點に示す通りである.こつに見られる如く $8 \%$ までつ領域 で罢アルミニウム成分による內部杽祭つ變化は少なく皆約 $1.5 \times 10^{-4}$ の值を示している. 注目すべきほ $1 \%$ 以下の アルミニウム戎分が微量つときに鑄造直後に大きく現われ た內部摩察 (Fig. 5 の直線 I ) が非常に減少している (Fig. 5 值線 II). Lか子振巾が大きいはどその差は大き い.またこれらの領域での彈性率熱彪理前とほとんど 變化がない. 炊にアルミニウムの成分が $8 \%$ を超すと

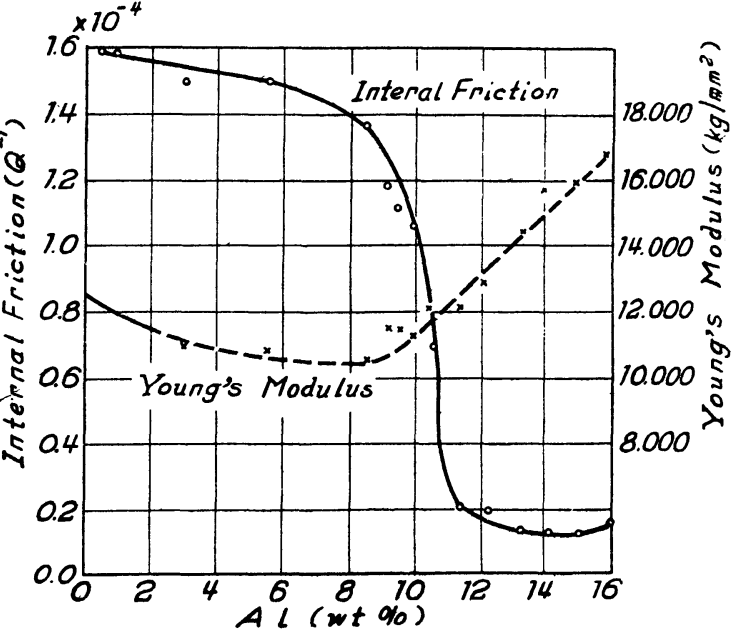

Fig 4 The effect of aluminium content on the internal frictios and Young's modulus of specimens annealed at $540^{\circ}$ for $12 \mathrm{hrs}$ after cast.

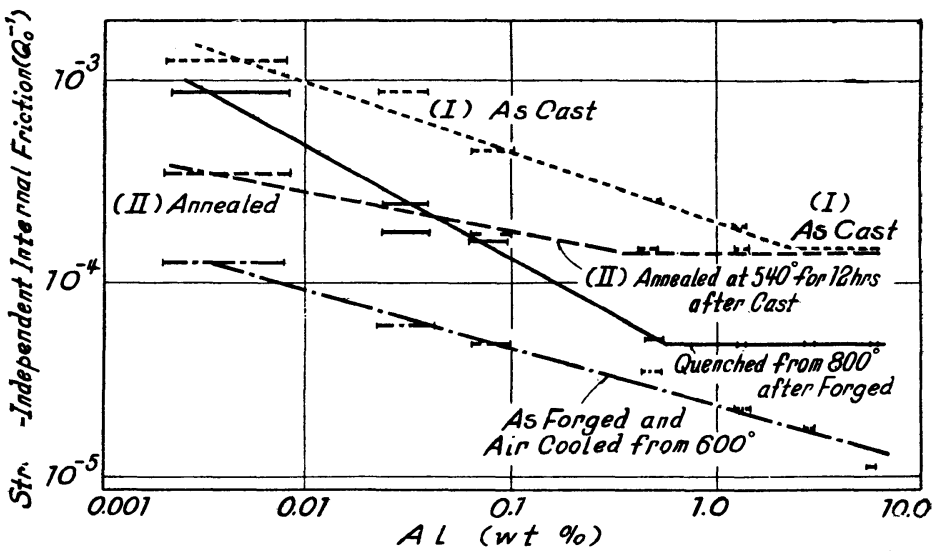

Fig. 5 Relation between the content of aluminium and the strain-independent internal friction. 
熱虎理により內部摩擦は急激に變化し，內部摩擦がそれぞ れ $5.9 \times 10^{-4}, 8.0 \times 10^{-4}$ および $1.04 \times 10^{-3}$ であつた 9.5, 10.5, および $11 \% \mathrm{Al}$ 成分の合金がそれぞれ, $1 \times$ $10^{-4}, 7 \times 10^{-5}, 2 \times 10^{-5}$ に低下した. その領域では內部 擦は 540 熱废理により甚しく低下しその代表である $12 \% \mathrm{Al}$ に括いては約 $1 / 200$ に減少している. またこの 領域でつ彈泩率はナルミニウムの成分が嘫加するとともに


を示している.

 数する測定結果}

(1) $800^{\circ}$ より $600^{\circ}$ の間で熱間鍛造し $600^{\circ}$ より宾冷し た試料について內部摩繁を測定した結果を Fig. 6 に示し

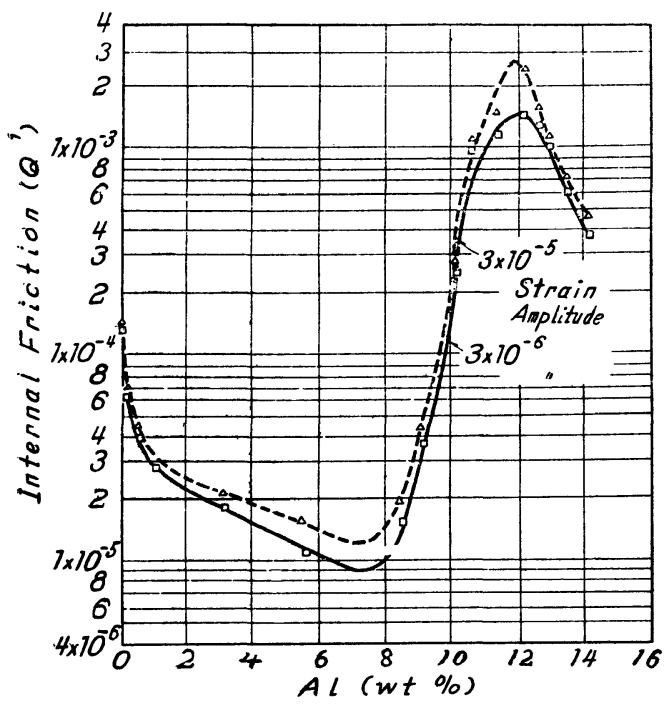

Fig. 6 The effect of aluminium content on the internal friction of specimens forged at temperature range of $800 \sim 600^{\circ}$ and air cooled.

た. $8 \%$ 以下の厂ルミニウム成分では溶貿濃度の壃加に從 つて票函數的に減少し (Fig. 5 の鋇線參照) Al $5 \%$ の試 料では $1.1 \times 10^{-5}$ といら非常に小さい値を示している. アルミニウム成分が $8 \%$ を超すと內部摩擦は急激に上升し 11.5 12\%の間で最大值 $1.5 \times 10^{-3}$ である. それ以上 のアルミニウム成分では內部摩擦は低下する. またこの鍛 造組織つ內部摩擦は振巾依存性は小さい. 鍛造後 $620^{\circ}$ て Ihr 燒鈍後室冷したもの>振巾非依存內部撃擦はほとんど 上記の鍛造後宾冷したものと等しいが，臨界歪振巾ほ小さ くなり內部摩擦の振巾侤存性は大きくなつている.

(2) 相組織と非彈性との關係を明確にするには加工組織 が完公に取り除かれるまで高溫度で十分熱處理した後に水 中に燒入れした試料について研究する方が望ましいと考え られるので, $800^{\circ}$ で $270 \mathrm{~min}$ 間加熱後水中に燒入れ, $48 \mathrm{hr}$ 經過後いろいろな振巾で內部摩擦と固有振動數を湘 定した. (48 hr の經過を待つたのは, 憢入谊後は時効變化 が甚しいからである. martensitic 組織が多い場合この時
効變化が 2 段の面白い湲化をするが，このことについて は別に報告する像定である). 測定結果は Fig. 7 に示 す. 振巾非依存内部摩擦はアルミニウム成分が 1\%まで

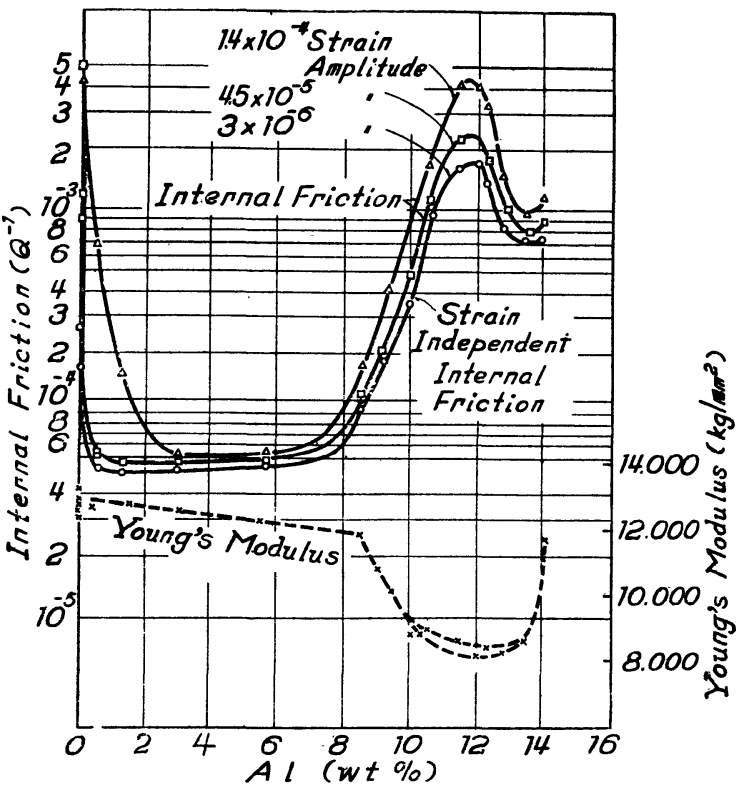

Fig. 7 The effect of aluminium content on the internal friction and Young's modulus of the specimens quenched from $800^{\circ}$ after annealing for 270 mins.

は指數呕數的に低下し，1\%より $8 \%$ までは約 $5 \times 10^{-5}$ の一定の值を示し, $8 \%$ 以上 11.5 12\% までは急激に上 并し 11.5〜 12\% で最大值約 $1.8 \times 10^{-3}$ を示し,この值は

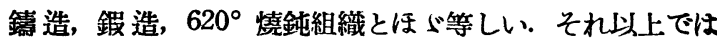
再び低下している. またアルミニウム成分が $3 \%$ 以下では 內部摩察つ振巾传存性は特に大きい(この振巾依存性は別 に報告の 豫定である). 次に彈性率は 同圖の點線にて示し た。燒入試料は試料つ寸法を正碓に仕上げたので, 固有振動 數から求めたこの彈性率は，試料の寸法の測定誤差内で正 確である.彈性率はアルミニウム成分が 8 \%まではアルミ

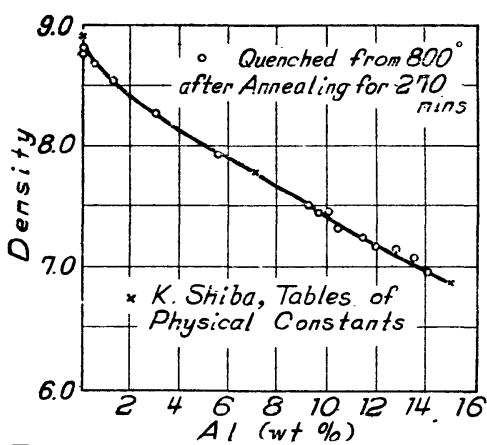

ニウムの堆加に比 例して徐々に低下 し, 8\% を超すと 急激に低下し, 10 〜13\%までは最 底值を示し(この 領域ではかなりバ ラッキが多い),そ れ以上になると再 び上界する.また

Fig. 8 Relation between centent of aluminium and density of $\mathrm{Cu}-\mathrm{Al}$ alloys quenched from $800^{\circ}$.

本試驗から測定し た比重は Fig. 8 の如くである.

\section{V.}

以上の實驗結果と各試料に對する顯徽鏡組織より，头の 
三つの現象について考察する. 一つはナルミニウム成分 8〜15\%の間に現われる martensitic 組織による異常に 高い內部摩察と低い彈性率であり，他は $\boldsymbol{\alpha}$ 相領域における 內部摩察に扣よぼす溶蟹譨度の影響と，鑄造，燒入による 不安定さから惁る影響である。

鑄造，銀浩，熱處理扣よび燒入れ組織つ內部摩擦はア ルミニウム成分 $8 \%$ より 11.5 12\%まではアルミニウ ムの增加とともに增大し，彈性率核逆に低下している. Fig. 2 の狀態首からも知られることであるが各試料の顯!票 鏡寫真 (Photo. 1) 參照)を見るとmartensiticな $\boldsymbol{\beta}^{\prime}$ 組織つ

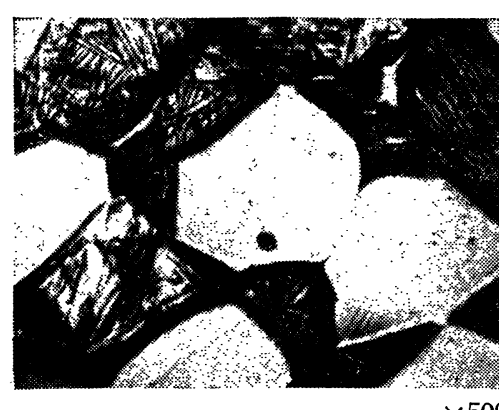

$\times 500$

Photo. 1 Micro structure of the specimen $(10 \% \mathrm{Al})$ quenched from $800^{\circ} .(\alpha+\beta)$
量の增加に從つ て內部摩嚓が咟 加していること が明瞭である. し加女共晶點 $(11.8 \% \mathrm{Al})$ 附近の成分でそ の內部摩丞の值 が極大となり, 鑄造, 鈮造, $620^{\circ}$ 憢鈍, $800^{\circ}$ より 燒入れたものが は前處理に依存せず約 $1.5 \sim 2 \times 10^{-3}$ 力値をとり, 彈性 率 皆逆に極小值をとること，扣よびこれらの試料を $560^{\circ}$ 以下で長特間澆鈍して共析變態させ $\boldsymbol{\alpha}+\gamma_{2}$ 組織にすると その內部嚤察は $1 \times 10^{-5}$ 程度に低下すること'からこの 異常に高い內部摩察が martensitic 組織けよることは明 かである. アルミニウム成分が共晶點以上になると內部 摩擦が低下し彈性率が上昇するのは $\gamma_{2}$ 相の霄加のためで あると考えられる. また martensitic 組織であれば $\beta^{\prime}$ 相 のみでなく $\gamma^{\prime}$ 相も同樣に高い內部摩擦を示している. こ の martensitic 組織試料の內部摩擦を 300 cycles/sec よ り $7,000 \mathrm{cycles} / \mathrm{sec}$ まで測定したがこの全領域で 1〜2入 10-3 の高い值をとり,あまり振動數に對する依存性を示さ ないのでこの組織で大きな內部摩擦をもたらす機構は C. Zener によつて提出された. standard rinear solid(5)より はむしろ martensitic 變刽によつて生じる轉位による寄與 のように思えるがこの點に關してに今後研究を行う娥定で ある.

次に $a$ 相户での現象であるが, Fig. 3, Fig.6 特よび Fig. 7 には內部揧察に對し溶賀アルミニウム濃度は直線尺

(5) S. Takahashi, J. Appl. Phys., 23(1952), 866.
度で圖示し, Fig. 5 には對數尺度で圖示したが, 振巾非体 存內部摩察は溶質濃度が小さいときは溶質濃度の增加に從 つて覃呕數的に減少している。しかもその絕對値は鑄造括 よび燒入れ組織のものふ熱間鋸造後室冷または熱處理後室 冷のものより大きい.これらの內部摩摖の要因として, (a) 轉位拉よび空格子，(b) C. Zener の外部歪刀による溶 質原子の選擇配列 ${ }^{(6)}$, (c) 熱潬性効果 ${ }^{(5)}$ が考兵られるが本 實驗は常溫で約 1000 cycles/sec を㬨いて行つたのであ るから，銅中のアルミニウム滰移動に要する活性化エ ネルギーから（b）の要因上土和摩擦は $10^{-5}$ 程度に はなり得ない(6)(7) (250ํ以上なつて初めて考慮を要す る程度になる). なた（c）は本試料の結晶粒度からして $1000 \mathrm{cycles} / \mathrm{sec}$ 附近で主測定值にほ寄與し得ない，それ 故，最も大きな要因として，(a）の要因，すなわち移動し 易い轉位と空格子が考えられる。内部摩檫は高溫より燒入 れした試料が高く，徐冷の試料が低いのは，前者では痓入 歪による塑性變形のために移動し易い轉位が多く，後者で ほ徐冷つために燒入の塑性變形を起すことが少ないのでそ れケシけ移動し易い轉位は少ないし，また途中の温度で不安 定な轉位はより安定な位置へ移偅なるためであろう，また 燒入䦽後に過飽和に存在する空格子は前者より後者が多く 消失していることが豫想される. 濃度に從つて內部摩擦が 減少するのは轉位が溶質原子によつて拘束されるために外 部振動㗹力による移動が困難となるためであると考えられ る（この點扣よび臨界歪力の溶貿濃度による變化は別に報 告する).

以上 $\mathrm{Cu}-\mathrm{Al}$ 合金の內部摩擦におよぼすアルミニウムの 濃度 (0〜16\% Al) の影響についての實驗結果を要約する と，(1) アルミニウム濃度の小さいところでは內部摩擦は 濃度に對し票㥛數的に低下する.（2）燒入溫度が高溫にな るほど $\propto$ 相の內部摩擦は大きくなる. (3) martensitic 組 織は異常に高い內部摩蔡 $\left(1 \sim 2 \times 10^{-3}\right)$ と低い彈性率を示 す. (4) $\alpha+\beta^{\prime}$ 相の組織つものは $\beta^{\prime}$ 組織の量に從つて內 部摩察が漂加し彈栍率は低下する.（5） $\gamma_{2}$ 相の內部摩擦は 非常に小さく彈性率は大きい.

最後に本研究に興味と指導と激勵を戴いた岩瀨 慶三教

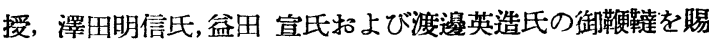
わりかつ發表を許可して下さつた三菱金䙓鑛業株式會社高 橋幸三郎常務取締役, 淺田寬二研究所長心深く感謝する。

(6) C. Zener, Elasticity and Unelasticity of Metals Univ., Chicago Press, (1948).

(7) C. Weert, J. Marx, Act. Met., 1(1953), 113. 